\title{
Experimental Study on Strength Parameters of Self Repairing Concrete
}

\author{
Panga Narasimha Reddy ${ }^{{ }^{*}}$, Bode Venkata Kavyateja ${ }^{2}$ \\ ${ }^{1}$ National Institute of Technology, Srinagar, Kashmir, India \\ ${ }^{2}$ JNTUA College of Engineering, Kalikiri, Andhra Pradesh, India
}

Corresponding Author Email: narasimha_07phd16@nitsri.ac.in

https://doi.org/10.18280/acsm.430505

Received: 15 July 2019

Accepted: 23 September 2019

\section{Keywords:}

durability of structures, bacillus subtilis, calcium lactate, calcium carbonate, microbial concrete, self healing cracks, rehabilitation, modulus of rupture, urea

\begin{abstract}
The microbial self-healing concrete has been a new technology to repair cracks, the former study showed that the precipitated $\mathrm{CaCO}_{3}$ could fill the cracks and reduce the permeability coefficient of cracks. This paper presents the effect on strength parameters with the addition of bacillus subtilis bacteria and calcium lactate. This study helps to improve the strength of self-repairing concrete with the use of bacillus subtilis bacteria and calcium lactate. The production of calcium carbonate in bacterial concrete is limited to the calcium content in cement. Hence calcium lactate is externally added to be an additional source of calcium in the concrete. The influence of this addition on compressive strength and modulus of rupture are highlighted in this study. The Bacillus subtilis bacteria and calcium lactate are mixed in concrete with different concentrations and tested for compressive and modulus of rupture of concrete. The results show that the performance of concrete improves with the addition of bacillus subtilis bacteria and calcium lactate into concrete.
\end{abstract}

\section{INTRODUCTION}

Concrete materials have the advantages of high compressive strength, better fireproofing and durability, easiness in obtaining materials [1], which have been widely used in many practical projects like water conservancy and hydropower, traffic, industrial and civil construction. They have become one of the most extensively used civil engineering materials. But during the preparation and usage of concrete, the external loads and other factors can result in loosing and spalling on the surface, seriously making cracks in the concrete. The cracks will reduce the capacities of antipermeability, anti-chloride-corrosion and anti-carbonization greatly, which can make the corrosion of interior reinforcements much easier and lower the carrying capacity and durability of structure. If the repair of concrete cracks isn't completed in time, it will affect the normal use of concrete structure, resulting in total destruction and even collapse. The traditional repairing methods are passive in most cases. They have complex technology, high cost and even some destructive effects on the environment, which can't satisfy the requirement of modern intelligence and multifunction for concrete materials. With the advancement in the technology, a novel approach to rehabilitating the cracks in concrete by itself has been developed and is termed as self-healing concrete. Microorganisms and calcium nutrient source are added during mixing of concrete results in the precipitation of calcium carbonate, providing it an inherent crack healing property [26]. The literature reported so far deals with different types of microorganisms used in concrete for self-healing of cracks [710] and its compatibility with different types of cement replacing materials like rice husk ash, fly ash, silica fume and cement baghouse filter dust [11-14]. The improvement in mechanical and durability of concrete using bacteria motivated some researchers to examine the effect of it on strength, chloride ion permeability and water permeability of concrete [15-17]. This reported betterment in the compressive strength and reduction in water and chloride ion permeability of concrete compared with the normal concrete.

In recent studies most of the work was carried out on, urea lytic microorganisms of the genus Bacillus for calcite precipitation. The basic phenomenon involves in this process is enzymatic hydrolysis of urea to carbon dioxide and ammonia leading to the formation of $\mathrm{CaCO}_{3}$. The detailed mechanism is being as follows [18].

$$
\begin{gathered}
\mathrm{CO}\left(\mathrm{NH}_{2}\right)_{2}+\mathrm{H}_{2} \mathrm{O} \rightarrow \mathrm{NH}_{2} \mathrm{COOH}+\mathrm{NH}_{3} \\
\mathrm{NH}_{2} \mathrm{COOH}+\mathrm{H}_{2} \mathrm{O} \rightarrow \mathrm{NH}_{3}+\mathrm{H}_{2} \mathrm{CO}_{3} \\
\mathrm{H}_{2} \mathrm{CO}_{3} \rightarrow \mathrm{HCO}_{3}^{-}+\mathrm{H}^{-} \\
2 \mathrm{NH}_{3}+2 \mathrm{H}_{2} \mathrm{O} \rightarrow 2 \mathrm{NH}_{4}^{+}+2 \mathrm{OH}^{-} \\
\mathrm{HCO}_{3}+\mathrm{H}^{+}+2 \mathrm{NH}_{4}^{+}+2 \mathrm{OH}^{-} \rightarrow \mathrm{CO}_{3}^{2-}+2 \mathrm{NH}_{4}^{+}+2 \mathrm{H}_{2} \mathrm{O}
\end{gathered}
$$

The cell wall of microorganism is negatively charged, the microorganisms draw cations from the surroundings, together with $\mathrm{Ca}^{2+}$, to deposit on their cell surface. The $\mathrm{Ca}^{2+}$ ions react with the $\mathrm{CO}_{3}{ }^{2-}$ prime to precipitation of calcium carbonate at the cell surface that fills in as a nucleation site. Figure 1 demonstrates the picture of $\mathrm{CaCO}_{3}$ precipitation on microorganism cell wall. Figure 1(a) shows the utilization of $\mathrm{CO}_{3}{ }^{2-}$ source by the microorganism, and emission of broke down inorganic carbon and ammonia into the extracellular space; Figure 1(b) $\mathrm{Ca}^{2+}$ ions in the micro environment of the bacterium; Figure 1(c) $\mathrm{Ca}^{2+}$ ions react with $\mathrm{CO}_{3}{ }^{2-}$ ions to form $\mathrm{CaCO}_{3}$ crystals.

$$
\mathrm{Ca}^{2+}+\text { Cell } \rightarrow \text { Cell }-\mathrm{Ca}^{2+}
$$




$$
\text { Cell }-\mathrm{Ca}^{2+}+\mathrm{CO}_{3}^{2-} \rightarrow \text { Cell }-\mathrm{CaCO}_{3}
$$
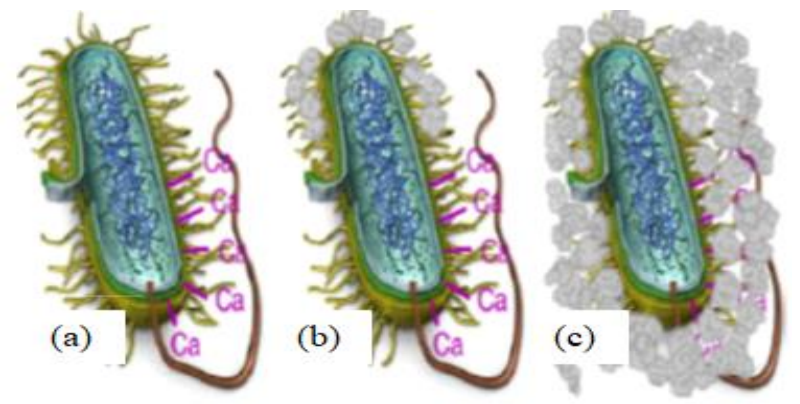

Figure 1. $\mathrm{CaCO}_{3}$ formation on bacterial cell wall [18]

However, the major limitation of this mechanism is two ammonium ions are simultaneously produced for each carbonate ion, which results emission of huge amount of nitrogen to the environment. This will cause harmful effect to the human beings. To avoid these problem researchers have used bacteria plus additional calcium source like calcium lactate, calcium acetate and calcium formate into the concrete. The following is an example for calcium carbonate precipitation by metabolic activity of bacteria using calcium lactate.

$$
\mathrm{C}_{6} \mathrm{H}_{10} \mathrm{O}_{6} \mathrm{Ca}+6 \mathrm{O}_{2} \stackrel{\text { Bacteria }}{\longrightarrow} \mathrm{CaCO}_{3}+5 \mathrm{CO}_{2}+5 \mathrm{H}_{2} \mathrm{O}
$$

The calcite based minerals produced will improve, when the produced $\mathrm{CO}_{2}$ molecules further reacts with $\mathrm{Ca}(\mathrm{OH})_{2}$ minerals. This is the product developed during hydration of concrete. The following expression (9) will give the details of secondary calcium carbonate deposition in concrete.

$$
5 \mathrm{CO}_{2}+\mathrm{Ca}(\mathrm{OH})_{2} \rightarrow \mathrm{CaCO}_{3}+5 \mathrm{H}_{2} \mathrm{O}
$$

This process can be looked into a substitute mechanism to existing urease based system studies [18]. In this method calcium lactate, calcium acetate, and calcium nitrate are used as calcium nutrient source [19-21] and reported as this method will give better results in healing of cracks. Very few researchers have been studied the pathway by the accumulation of microorganisms along with calcium lactate.

The main objective of the work is to study the performance of bacterial concrete by the addition of bacillus subtilis microorganisms along with calcium lactate. Prior to casting, addition of bacillus subtilis bacteria and calcium lactate to the concrete, this will stay feasible for a longer period. This helps to generate huge amount of minerals needed to heal the freshly formed cracks. This process of self-healing saves rehabilitation effort along with increased durability of the structure. Also, this process reduces the maintenance cost besides being eco-friendly.

\section{MATERIALS AND METHODS}

\subsection{Materials}

In this study Ordinary Portland cement (OPC) is used as a binder. The coarse aggregate and fine aggregate are used as filler materials along with calcium lactate and bacillus subtilis bacteria. OPC is tested as per Indian Specifications IS: 40311988 [22]. The fine and coarse aggregates are tested as per Indian Specifications IS: 383-1970 [23]. The $20 \mathrm{~mm}$ and 4.75 $\mathrm{mm}$ as the maximum size of coarse and fine aggregate respectively have been used. Calcium lactate was procured from the Triveni Chemicals, Gujarat India, with properties as per Indian Pharma. Bacillus subtilis microorganisms were procured from the Retron probiotics Pvt Ltd, Vijayawada (In the form of spore powder) [24]. The same was cultured in a nutrient broth made with yeast extract $2.0 \mathrm{gm} / 1, \mathrm{NaCl} 5.0 \mathrm{gm} / 1$, peptone $5.0 \mathrm{gm} / 1$, beef extract $1.0 \mathrm{gm} / 1$, and distilled water $(\mathrm{pH}$ $=7.0$ ). These samples were investigated for the identification of isolated bacteria. Table 1 lists the investigated data [25-29].

Table 1. Investigated data for identification of microorganism

\begin{tabular}{|c|c|c|c|}
\hline Test performed & Used Indicator & Colour Observation & Results \\
\hline Gram staining reaction & Crystal violet & Purple & Gram positive \\
\hline Urease test & Phenol red indicator and urea & Pink & Gram positive \\
\hline
\end{tabular}

Table 2. Details of concrete mix design per cubic meter

\begin{tabular}{|c|c|c|c|c|c|c|c|}
\hline $\begin{array}{c}\text { Mix } \\
\text { No }\end{array}$ & $\begin{array}{c}\text { Mix } \\
\text { Name }\end{array}$ & $\begin{array}{c}\text { Cement } \\
\left(\mathbf{k g} / \mathbf{m}^{\mathbf{3}}\right)\end{array}$ & $\begin{array}{c}\text { Fine aggregate } \\
\left(\mathbf{k g} / \mathbf{m}^{\mathbf{3}}\right)\end{array}$ & $\begin{array}{c}\text { Coarse aggregate } \\
\left(\mathbf{k g} / \mathbf{m}^{\mathbf{3}}\right)\end{array}$ & $\begin{array}{c}\mathbf{W a t e r} \\
\left(\mathbf{k g} / \mathbf{m}^{\mathbf{3}}\right)\end{array}$ & $\begin{array}{c}\text { Bacteria } \\
(\mathbf{c f u} / \mathbf{m l})\end{array}$ & $\begin{array}{c}\text { Calcium lactate } \\
\left(\mathbf{k g} / \mathbf{m}^{\mathbf{3}}\right)\end{array}$ \\
\hline Mix 1 & CM & 394 & 675.3 & 1227.5 & 157.6 & Nil & Nil \\
\hline Mix 2 & C0.25 & 394 & 675.3 & 1227.5 & 157.6 & Nil & 0.985 \\
\hline Mix 3 & C0.5 & 394 & 675.3 & 1227.5 & 157.6 & Nil & 1.97 \\
\hline Mix 4 & C1 & 394 & 675.3 & 1227.5 & 157.6 & Nil & \\
\hline Mix 5 & B4 & 394 & 675.3 & 1227.5 & 157.6 & $10^{4}$ & Nil \\
\hline Mix 6 & B5 & 394 & 675.3 & 1227.5 & 157.6 & $10^{5}$ & Nil \\
\hline Mix 7 & B6 & 394 & 675.3 & 1227.5 & 157.6 & $10^{6}$ & Nil \\
\hline
\end{tabular}

\subsection{Methods}

The mechanical properties of concrete are calculated by conducting compressive strength and flexural strength tests on concrete. The compressive strength test has been performed in a compression testing machine of $2000 \mathrm{KN}$ capacity as per IS: 516 - 1959 [30-31], for control and microbial concrete cubes with a curing period of 7, 28 and 56 days. Modulus of rupture tests of control and microbial concrete are found by testing concrete beams of size $500 \mathrm{~mm}$ x $100 \mathrm{~mm}$ x $100 \mathrm{~mm}$ and testing was done by using two point loading as per IS: $516-$ 1959 [31]. The testing has been done at an age of 28 and 56 days of curing samples. 


\section{ESULTS AND DISCUSSION}

\subsection{Compressive strength}

The compressive strength results of the control and microbial concrete at a curing period of 7,28 and 56 days respectively are shown in Figure 3. Figure 2(a) depicts the compressive strength results of concrete only with the addition of bacteria. From these it is noticed that the strength improvement is modest only with the addition of bacteria.

Figure 2(b) depicts the compressive strength results of concrete only with the addition of calcium lactate. The addition of calcium lactate in concrete also somewhat improves the compressive strength of the concrete. From Figure 2(c) to 2(e) depicts the compressive strength results of concrete with different concentrations of bacteria and different dosages of calcium lactate. From these it is observed that the addition of bacteria with calcium lactate greatly improves the strength of the concrete. This is because of plugging of pores in concrete matrix by calcite precipitation. This enhancement of compressive strength continues till the bacterial concentration increases up to $10^{5} \mathrm{cfu} / \mathrm{ml}$ and reduces slightly with $10^{6} \mathrm{cfu} / \mathrm{ml}$. Similar pattern was observed with calcium lactate dosages also.

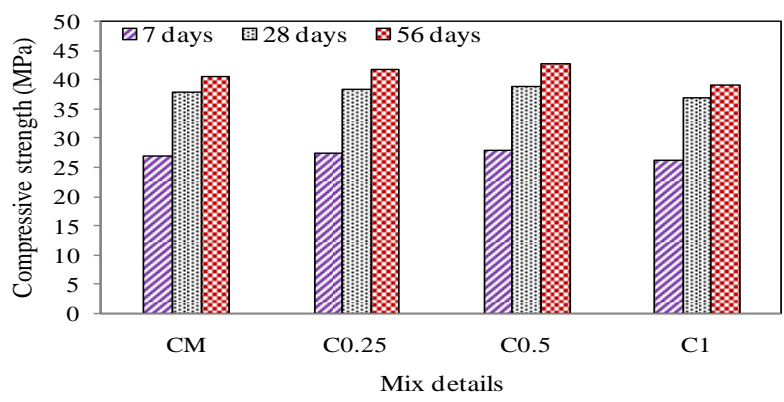

(a) Only the addition of calcium lactates

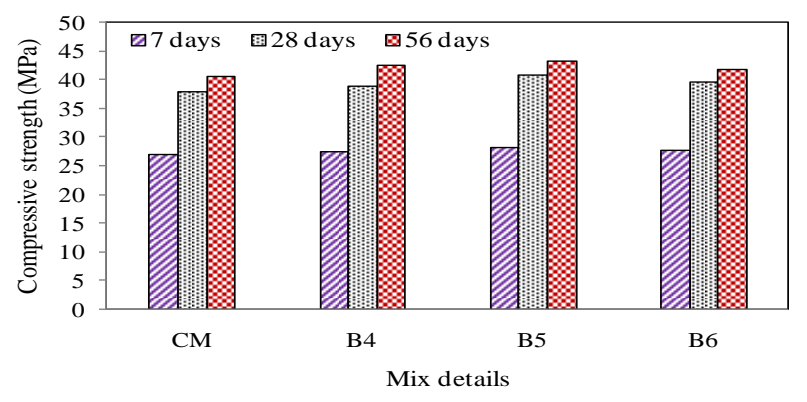

(b) Only the addition of bacteria

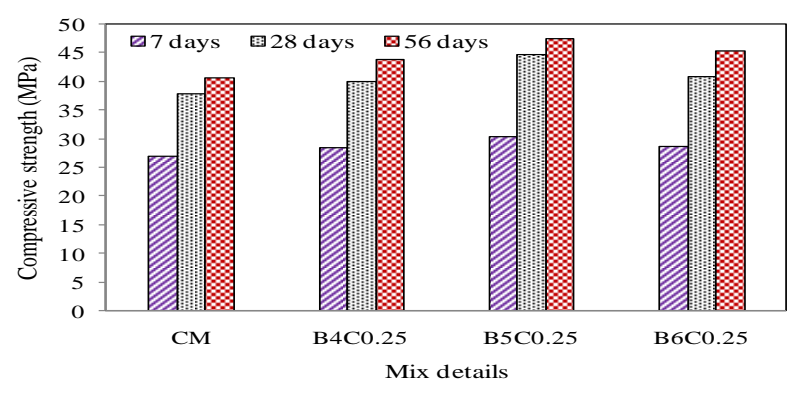

(c) $0.25 \%$ of calcium lactate and different concentrations of bacteria

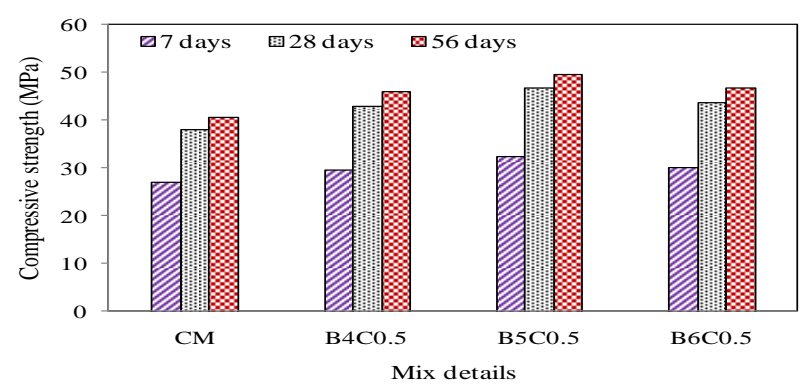

(d) $0.5 \%$ calcium lactate and different concentrations of bacteria

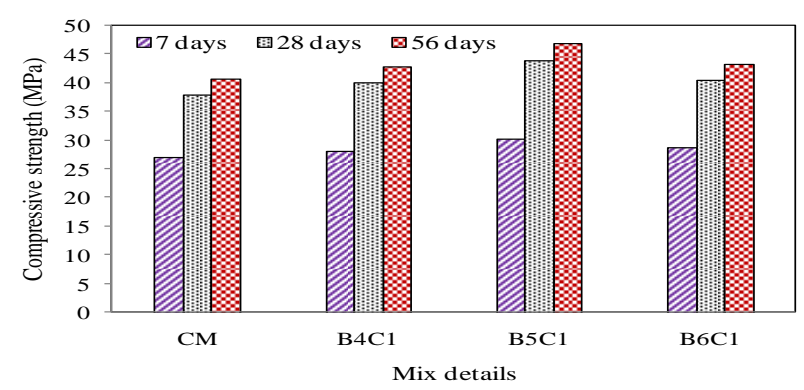

(e) $1 \%$ calcium lactate and different concentrations of bacteria

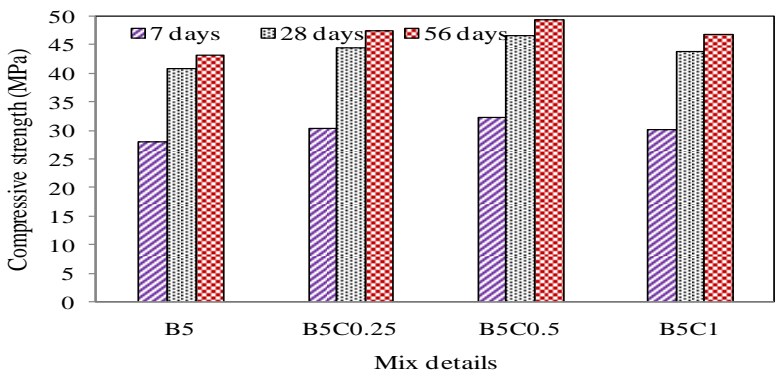

(f) $10^{5} \mathrm{cfu} / \mathrm{ml}$ concentration of bacteria and different dosages of calcium lactate

Figure 2. Compressive strength of normal and microbial concrete

Figure 2(f) depicts the compressive strength results of concrete with $10^{5} \mathrm{cfu} / \mathrm{ml}$ concentration of bacteria and different dosages of calcium lactate. The compressive strength is observed to have maximum enhancement at all ages with $10^{5} \mathrm{cfu} / \mathrm{ml}$ bacterial concentration and $0.5 \%$ of calcium lactate. Compressive strength results show an improvement of $20 \%$ by the addition $0.5 \%$ of calcium lactate and $10^{5} \mathrm{cfu} / \mathrm{ml}$ bacterial concentrations as compared with normal concrete. But the addition of more amount of calcium lactate reduces the compressive strength of concrete which is shown in Figure 2(f).

\subsection{Modulus of rupture}

Figure 3 depicts the modulus of rupture results control and microbial concrete at a curing period of 28 and 56 days. The results show that there is an improvement in the flexural strength of microbial concrete in all ages of curing. Figure 3(a) shows the modulus of rupture results concrete only with the addition of bacteria and Figure 3(b) shows the modulus of 
rupture results of concrete only with addition of calcium lactate. From these it is noticed that there is a slight enhancement in modulus of rupture with the addition of only bacteria and calcium lactate. Like compressive strength results similar pattern is followed for modulus of rupture.

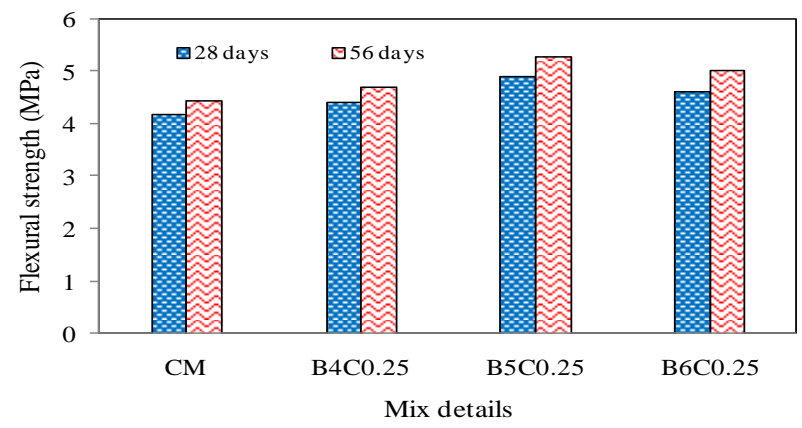

(a) $\quad 0.25 \%$ of calcium lactate and different concentrations of bacteria

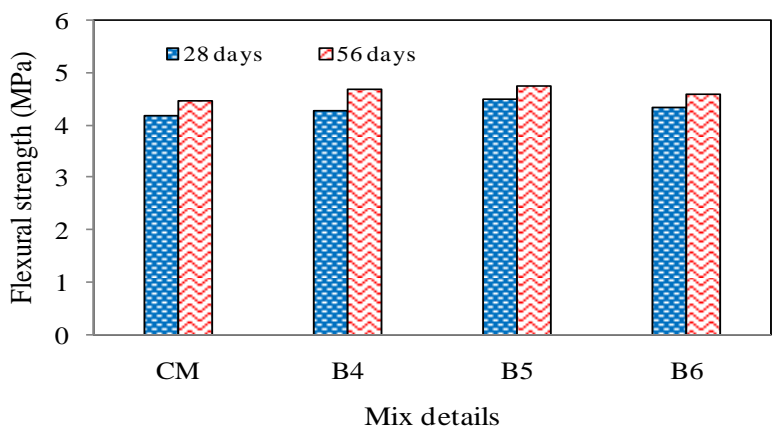

(b) Only the addition of bacteria

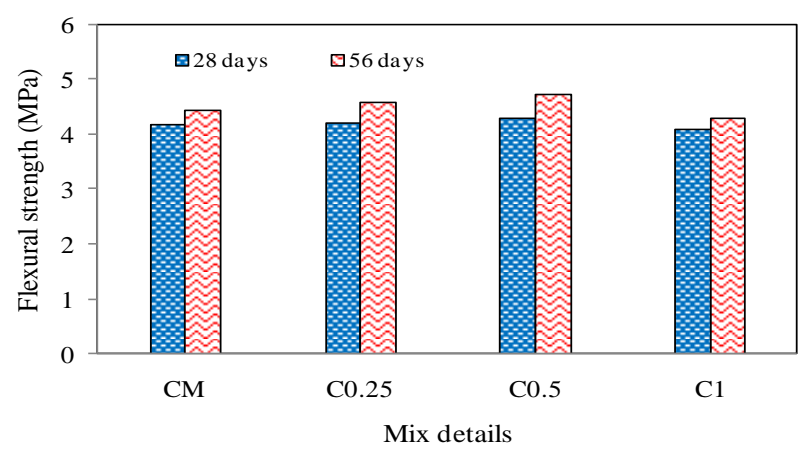

(c) Only the addition of calcium lactate

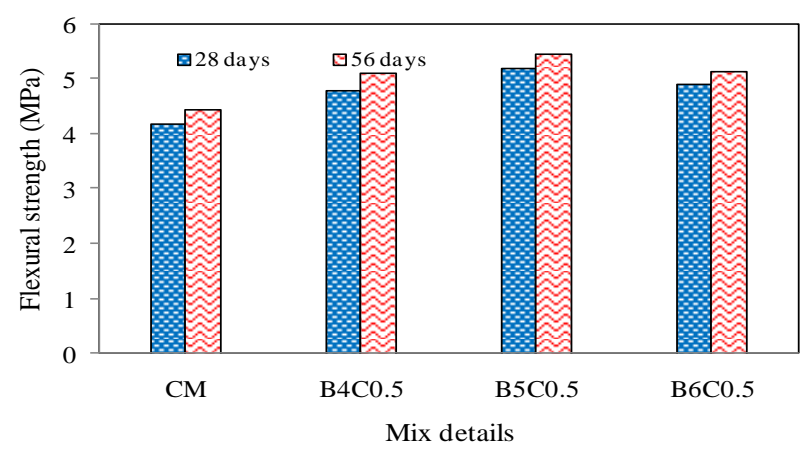

(d) $0.5 \%$ calcium lactate and different concentrations of bacteria

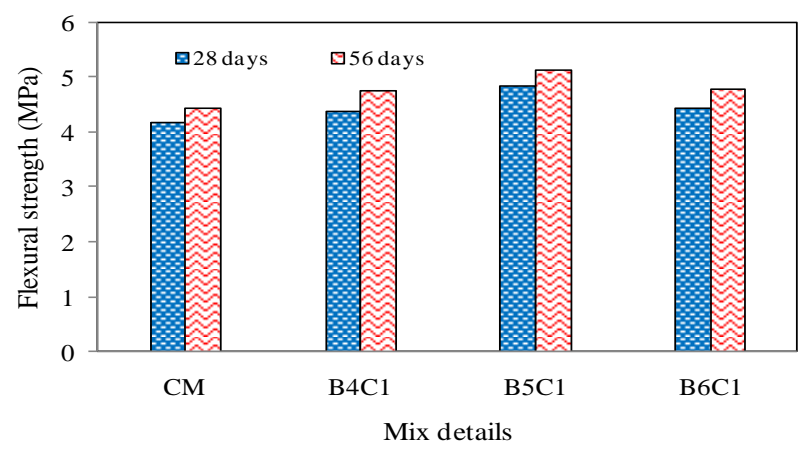

(e) $1 \%$ calcium lactate and different concentrations of bacteria

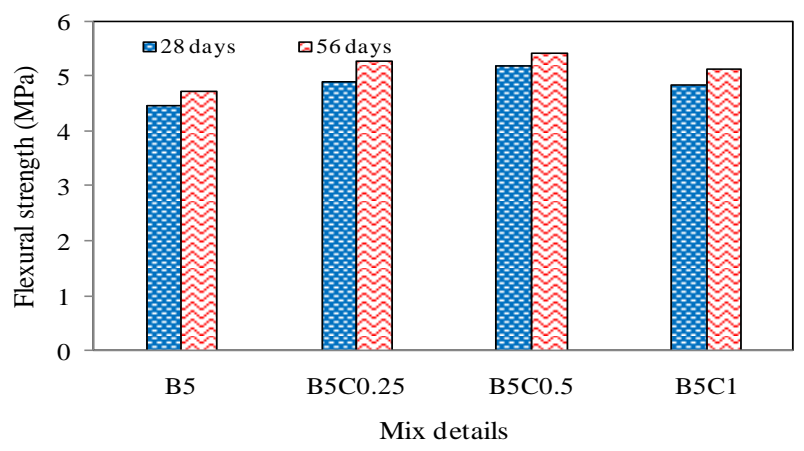

(f) $10^{5} \mathrm{cfu} / \mathrm{ml}$ concentration of bacteria and different dosages of calcium lactate

Figure 3. Flexural strength of normal and microbial concrete

From Figure 3(c) to 3(e) depicts the modulus of rupture results of concrete with different concentration of bacteria and different dosages of calcium lactate. There is a noticeable development in modulus of rupture results of concrete together with bacteria and calcium lactate. The enhancement of strength is due to plugging of pores with calcium carbonate in concrete matrix.

Figure 3(f) shows the modulus of rupture results of concrete with $10^{5} \mathrm{cfu} / \mathrm{ml}$ concentration of bacteria and different dosages of calcium lactate. From this it is observed that there is an optimum improvement in modulus of rupture with $10^{5} \mathrm{cfu} / \mathrm{ml}$ bacteria concentration and $0.5 \%$ dosages of calcium lactate. But the addition of more amounts of calcium lactate and bacteria reduce the strength of concrete this may be due to over precipitation of calcite at surface region. In addition to, the availability of water at the surface is equal in all samples. So, the precipitation highly depends on the concentration of bacteria and calcium lactate added. As a great number of micro-organisms precipitates more amount of $\mathrm{CaCO}_{3}$ in the presence of calcium lactate. The maximum amount of precipitation takes place at the maximum cell concentrations and higher amounts of calcium lactate at the surface province of the concrete. However, the over precipitation of $\mathrm{CaCO}_{3}$ on the surface may reduce the strength of concrete.

\section{CONCLUSIONS}

In this study, the effect of bacillus subtilis bacteria and calcium lactate on mechanical performance of concrete was investigated. The observations and the results obtained 
verified the enhancement in the mechanical performance of microbial concrete with the addition of bacteria and calcium lactate. The improvement in strength of microbial concrete was because of the precipitation of calcite by bacterial activity. The bacterial concentration $10^{5} \mathrm{cfu} / \mathrm{ml}$ and $0.5 \%$ addition of calcium lactate in concrete, the compressive strength is observed to have maximum enhancement at all ages. The maximum pore filling was observed to be achieved at a cell concentration $10^{6} \mathrm{cfu} / \mathrm{ml}$ concentrations of bacteria and an addition of $1 \%$ of calcium lactate using the surface analysis. The precipitation of calcite at the surface region acts as a guard to protect the inner matrix from the diffusion of water and harmful substances into the concrete.

\section{ACKNOWLEDGMENT}

The authors acknowledge the National Institute of Technology, Srinagar, (Jammu and Srinagar), providing laboratory testing facility. The authors are further thankful for the Ambuja Cement Ltd, Goa and BASF chemicals, Mumbai for providing the required material.

\section{REFERENCES}

[1] Shaikh, F.U.A. (2018). Effect of cracking on corrosion of steel in concrete. International Journal of Concrete Structures and Materials, 12: 3. https://doi.org/10.1186/s40069-018-0234-y

[2] Vijay, K., Murmu, M., Deo, S.V. (2017). Bacteria based self healing concrete - A review. Constr. Build. Mater., 152: 1008-1014. https://doi.org/10.1016/j.conbuildmat.2017.07.040

[3] Andalib, R., Majid, M.Z.A., Hussin, M.W., Mohanadoss, P. (2016). Optimum concentration of Bacillus megaterium for strengthening structural concrete. Constr. Build. $\quad$ Mater., 118: 180-193. https://doi.org/10.1016/j.conbuildmat.2016.04.142

[4] Bang, S.S., Lippert, J.J., Yerra, U., Mulukutla, S. (2014). Microbial calcite, a bio-based smart nanomaterial in concrete remediation. International Journal of Smart and Nano $\quad$ Materials, $\quad 1(1)$ : 28-39. https://doi.org/10.1080/19475411003593451

[5] De Belie, N., Wang, J. (2015). Bacteria-based repair and self-healing of concrete. Journal of Sustainable CementBased Materials, 5: 35-56. https://doi.org/10.1080/21650373.2015.1077754

[6] Guo, Y.C., Wang, X., Yan, Z., Zhong, H. (2016). Current progress on biological self-healing concrete Material Research Innovations, 19(S8): 750-753. http://dx.doi.org/10.1179/1432891715Z.000000000179 2.

[7] Luo, M., Qian, C.X., Li, R.Y., Rong, H. (2015). Efficiency of concrete crack-healing based on biological carbonate precipitation. Journal of Wuhan University of Technology-Mater. Sci. Ed., 30(6): 1255-1259. http://dx.doi.org/10.1007/s11595-015-1304-5

[8] Wiktor, V., Jonkers, H.M. (2011). Quantification of crack-healing in novel bacteria-based self-healing concrete. Cem. Concr. Compos., 33(7): 763-770. https://doi.org/10.1016/j.cemconcomp.2011.03.012

[9] Khaliq,W., Ehsan, M.B. (2016). Crack healing in concrete using various bio influenced self-healing techniques. Constr. Build. Mater., 102: 349-357. https://doi.org/10.1016/j.conbuildmat.2015.11.006

[10] Tziviloglou, E., Wiktor, V., Jonkers, H.M., Schlangen, E. (2016). Bacteria-based self-healing concrete to increase liquid tightness of cracks. Constr. Build. Mater., 122: 118-125. https://doi.org/10.1016/j.conbuildmat.2016.06.080

[11] Chahal, N., Siddique, R., Rajor, A. (2012). Influence of bacteria on the compressive strength, water absorption and rapid chloride permeability of concrete incorporating silica fume. Constr. Build. Mater., 37(1): 645-651. https://doi.org/10.1016/j.conbuildmat.2012.07.029

[12] Siddique, R., Singh, K., Kunal, Singh, M., Corinaldesi, V., Rajor, A. (2016). Properties of bacterial rice husk ash concrete. Constr. Build. Mater., 121: 112-119. https://doi.org/10.1016/j.conbuildmat.2016.05.146

[13] Chahal, N., Siddique, R., Rajor, A. (2012). Influence of bacteria on the compressive strength, water absorption and rapid chloride permeability of fly ash concrete. Constr. Build. Mater., 28(1): 351-356. https://doi.org/10.1016/j.conbuildmat.2011.07.042

[14] Siddique, R., Nanda, V., Kunal, Kadri, E.H., Khan, M.I., Singh, M., Rajor, A. (2016). Influence of bacteria on compressive strength and permeation properties of concrete made with cement baghouse filter dust. Constr. Build. Mater., 106: 461-469. https://doi.org/10.1016/j.conbuildmat.2015.12.112

[15] Mondal, S., Ghosh, A.D. (2018). Investigation into the optimal bacterial concentration for compressive strength enhancement of microbial concrete. Constr. Build. Mater., 183: 202-214. https://doi.org/10.1016/j.conbuildmat.2018.06.176

[16] Achal, V., Pan, X., Özyurt, N. (2011). Improved strength and durability of fly ash-amended concrete by microbial calcite precipitation. Ecol. Eng., 37(4): 554-559. https://doi.org/10.1016/j.ecoleng.2010.11.009

[17] Nosouhian, F., Mostofinejad, D., Hasheminejad, H. (2016). Concrete durability improvement in a sulfate environment using bacteria. Journal of Materials in Civil Engineering, 28(1): 1-12. http://dx.doi.org/10.1061/(ASCE)MT.19435533.0001337

[18] Siddique, R., Kaur, N. (2011). Effect of ureolytic bacteria on concrete properties. Constr. Build. Mater., 25(10): 3791-3801. https://doi.org/10.1016/j.conbuildmat.2011.04.010

[19] Jonkers, H.M., Thijssen, A., Muyzer, G., Copuroglu, O., Schlangen, E. (2010). Application of bacteria as selfhealing agent for the development of sustainable concrete. Ecol. Eng., 36: 230-235. https://doi.org/10.1016/j.ecoleng.2008.12.036

[20] Vijay, K., Murmu, M. (2018). Effect of calcium lactate on compressive strength and self-healing of cracks in microbial concrete. Frontiers of Structural and Civil Engineering. https://doi.org/10.1007/s11709-018-04942

[21] Irwan, J.M., Anneza, L.H., Othman, N., Alshalif, A.F., Zamer, M.M. (2016). Calcium lactate addition in bioconcrete: Effect on compressive strength and water penetration. MATEC Web of Conferences, 78: 01027. https://doi.org/10.1051/matecconf/20167801027

[22] BIS. 8112, Indian Standard 43 Grade Ordinary Portland Cement-Specification, Bureau of Indian Standards. 1989

[23] BIS. 383, Specifications for Coarse and Fine Aggregates 
from Natural Sources for Concrete. 1970.

[24] BIS. 10262, Guidelines for Concrete Mix Design Proportioning, Bureau of Indian Standards. 2009.

[25] Awolusi, T.F., Oke, O.L., Akinkurolere, O.O., Sojobi, A.O. (2019). Application of response surface methodology: Predicting and optimizing the properties of concrete containing steel fibre extracted from waste tires with limestone powder as filler. Case Studies in Construction

Materials. https://doi.org/10.1016/j.cscm.2018.e00212

[26] Zhang, Y., Guo, H.X., Cheng, X.H., Caco, C.A., Ca, C.A. (2014). Role of calcium sources in the strength and microstructure of microbial mortar. Constr. Build. Mater., 77: 160-167. https://doi.org/10.1016/j.conbuildmat.2014.12.040

[27] Luo, M., Qian, C. (2016). Influences of bacteria-based self-healing agents on cementitious materials hydration kinetics and compressive strength. Constr. Build. Mater., 121:

659-663. https://doi.org/10.1016/j.conbuildmat.2016.06.075

[28] Kanthe, V.N., Deo, S.V., Murmu, M. (2018). Effect of fly ash and rice husk ash on strength and durability of binary and ternary blend cement mortar. Asian Journal of Civil Engineering, 19(8): 963-970. https://doi.org/10.1007/s42107-018-0076-6

[29] Azarsa, P., Gupta, R. (2017). Electrical resistivity of concrete for durability evaluation: A review. Adv. Mater. Sci. Eng., 2017(1): 1-30. https://doi.org/10.1155/2017/8453095

[30] Bureau of Indian Standard. (1959). Methods of sampling and analysis of concrete. IS, 1199, 1-49.

[31] Bureau of Indian Standard. (1959). Indian standard methods of tests for strength of concrete. IS, 516, 1-30. 